\title{
Rethinking soil water repellency and its management
}

Article

Accepted Version

Ruthrof, K. X., Hopkins, A. J. M., Danks, M., O'Hara, G., Bell, R., Henry, D., Standish, R., Tibbett, M., Howieson, J., Burgess, T. and Harper, R. (2019) Rethinking soil water repellency and its management. Plant Ecology, 220 (10). pp. 977-984. ISSN 1385-0237 doi: https://doi.org/10.1007/s11258019-00967-4 Available at https://centaur.reading.ac.uk/85730/

It is advisable to refer to the publisher's version if you intend to cite from the work. See Guidance on citing.

To link to this article DOI: http://dx.doi.org/10.1007/s11258-019-00967-4

Publisher: Springer

All outputs in CentAUR are protected by Intellectual Property Rights law, including copyright law. Copyright and IPR is retained by the creators or other copyright holders. Terms and conditions for use of this material are defined in the End User Agreement.

\section{www.reading.ac.uk/centaur}

\section{CentAUR}

Central Archive at the University of Reading 
Reading's research outputs online 
3 Katinka X. Ruthrof (CO $)^{1,2 *}$, Anna J.M. Hopkins (CO $)^{3}$, Melissa Danks ${ }^{3}$, Graham O’Hara ${ }^{4}$, Richard 4 Bell $^{4}$, David Henry ${ }^{5}$, Rachel Standish ${ }^{1}$, Mark Tibbett ${ }^{6}$, John Howieson ${ }^{4}$, Treena Burgess ${ }^{1}$ and Richard 5 Harper $^{1}$

6

$7 \quad{ }^{1}$ Environmental and Conservation Sciences, Murdoch University, Murdoch, 6150, Western Australia, 8 Australia.

9 '2Biodiversity and Conservation Science, Department of Biodiversity, Conservation and Attractions, 10 Kensington, 6151, Western Australia, Australia.

$11{ }^{3}$ Centre for Ecosystem Management, Edith Cowan University, Joondalup, 6027, Western Australia, 12 Australia.

$13{ }^{4}$ Agricultural Sciences, Murdoch University, Murdoch, 6150, Western Australia, Australia.

$14{ }^{5}$ Chemistry and Physics, Murdoch University Murdoch, 6150, Western Australia, Australia

$15{ }^{6}$ School of Agriculture, Policy and Development, Reading University, Berkshire, RG6 6AH, United 16 Kingdom.

17 *Corresponding author: Katinka Ruthrof: k.ruthrof@murdoch.edu.au

18 (CO): KXR and AJMH are co-first authors of this paper.

19

20 ORCID Numbers:

21 Katinka Ruthrof: orcid.org/0000-0003-2038-2264 
Anna Hopkins: orcid.org/0000-00018090-5544

Melissa Danks: https://orcid.org/0000-0002-4044-6694

Graham O’Hara:

Richard Bell: orcid.org/0000-0002-7756-3755

David Henry: orcid.org/0000-0002-9629-4423

Rachel Standish: orcid.org/0000-0001-8118-1904

Mark Tibbett: orcid.org/0000-0003-0143-2190

John Howieson: orcid.org/0000-0002-1235-1903

Treena Burgess: orcid.org/0000-0002-7962-219X

Richard Harper: orcid.org/0000-0003-0268-2917

Abstract Soil water repellency (SWR) is a widespread challenge to plant establishment and growth.

Despite considerable research, it remains a recalcitrant problem for which few alleviation technologies or solutions have been developed. Previous research has focused on SWR as a problem to be overcome, however, it is an inherent feature of many native ecosystems where it contributes to ecosystem functions. Therefore, we propose a shift in the way SWR is perceived in agriculture and in ecological restoration, from a problem to be solved, to an opportunity to be harnessed. A new focus on potential ecological benefits of SWR is particularly timely given increasing incidence, frequency and severity of hotter droughts in many regions of the world. Our new way of conceptualising SWR seeks to understand how SWR can be temporarily alleviated at a micro-scale to successfully establish plants, and then harnessed in the longer term and at larger spatial scales to enhance soil water storage to act as a "drought-proofing" tool for plant survival in water-limited soils. For this to occur, we suggest research focusing on the alignment of physico-chemical and microbial properties and dynamics of SWR and, based on this mechanistic understanding, create products and interventions to improve success of plant establishment in agriculture, restoration and conservation contexts. In this paper, we outline the rationale for a new way of conceptualising SWR, and the research priorities needed to fill critical knowledge gaps in order to harness the ecological benefits from managing SWR.

Keywords: Drought, Fertiliser, Hydrophobicity, Microbial Activity, Nonwetting Soils, Run-off

\section{Introduction}

53 Soil water repellency (SWR) restricts soil water infiltration (DeBano 1981) and is a widespread 54 challenge to plant establishment and growth in many regions (Blackwell 2000; Doerr et al. 2000). It has been ranked as one of the major soil constraints to successful agriculture, for example, production losses of up to $80 \%$ have been reported in Australia (Blackwell 1993). Soil water repellency is not 
57 limited to particular climates, soil types or land uses. It occurs in tropical to subarctic climates, in dry 58 regions such as the United States (California, Oregon, and Utah), southern Australia (New South Wales, 59 South Australia, and Western Australia), the Mediterranean Basin (Italy, Portugal), but also in wetter 60 regions such as British Columbia, Sweden, Great Britain the Netherlands, and Columbia) (Mallik and 61 Rahmann 1985; Berglund and Persson 1996; Doerr et al. 2000). It affects soils of different textures from sand to clay (Dekker et al. 1998, Fig. 1), but is predominantly associated with soils with smaller surface areas and coarse texture, such as sands (Woche et al. 2005). In the Netherlands, an estimated $75 \%$ of crop and grassland soils exhibit SWR (Dekker \& Ritsema 1994) and across southern Australia, 2-5 million hectares are affected (House 1991). Soil water repellency is also induced by forest fires, under some vegetation types (Debano 2000; Doerr et al. 2000). Soil water repellency has been reported for cropping, pasture, shrubland, and forest soils. However, its specific occurrence is difficult to predict (McKissock et al. 1998). Collectively, these studies underscore the diversity of environments where SWR occurs and highlight the need for research to deliver practical outcomes for management.

Current understanding of the key factors causing SWR centre around the presence of hydrophobic, aliphatic $\mathrm{C}-\mathrm{H}$ compounds, derived from plant residues and exudates and micro-organisms, or from decomposing soil organic matter, which also originates from plants, animals and microbes (Doerr et al. 2005) (Fig. 1). It is most likely that low molecular weight, amphiphilic organic molecules are directly responsible for SWR. These hydrophobic organic compounds coat the surface of sand grains, or are intermixed with soil particles, and cause reduced and uneven infiltration of water into soils (Bond 1964). However, such hydrophobic compounds only represent a small proportion of soil organic matter. Moreover, such compounds may occur even in wettable soils. Hence, the degree of hydrophobicity has been explained by the amount of the hydrophobic aliphatic compounds, their origin, hydration status and intermolecular arrangement on the soil particles and soil surface area (Doerr et al. 2005; Diehl 2013; Uddin et al. 2017; Daniel et al. 2019). Dynamic changes in hydrophobicity can occur due to changes in soil water content, $\mathrm{pH}$, ionic strength and temperature (Diehl 2013). Microbial transformations of soil organic matter are also likely to determine the type and concentration of low molecular weight, watersoluble organic compounds responsible for SWR (Fig. 1) (Lowe et al. 2019). 


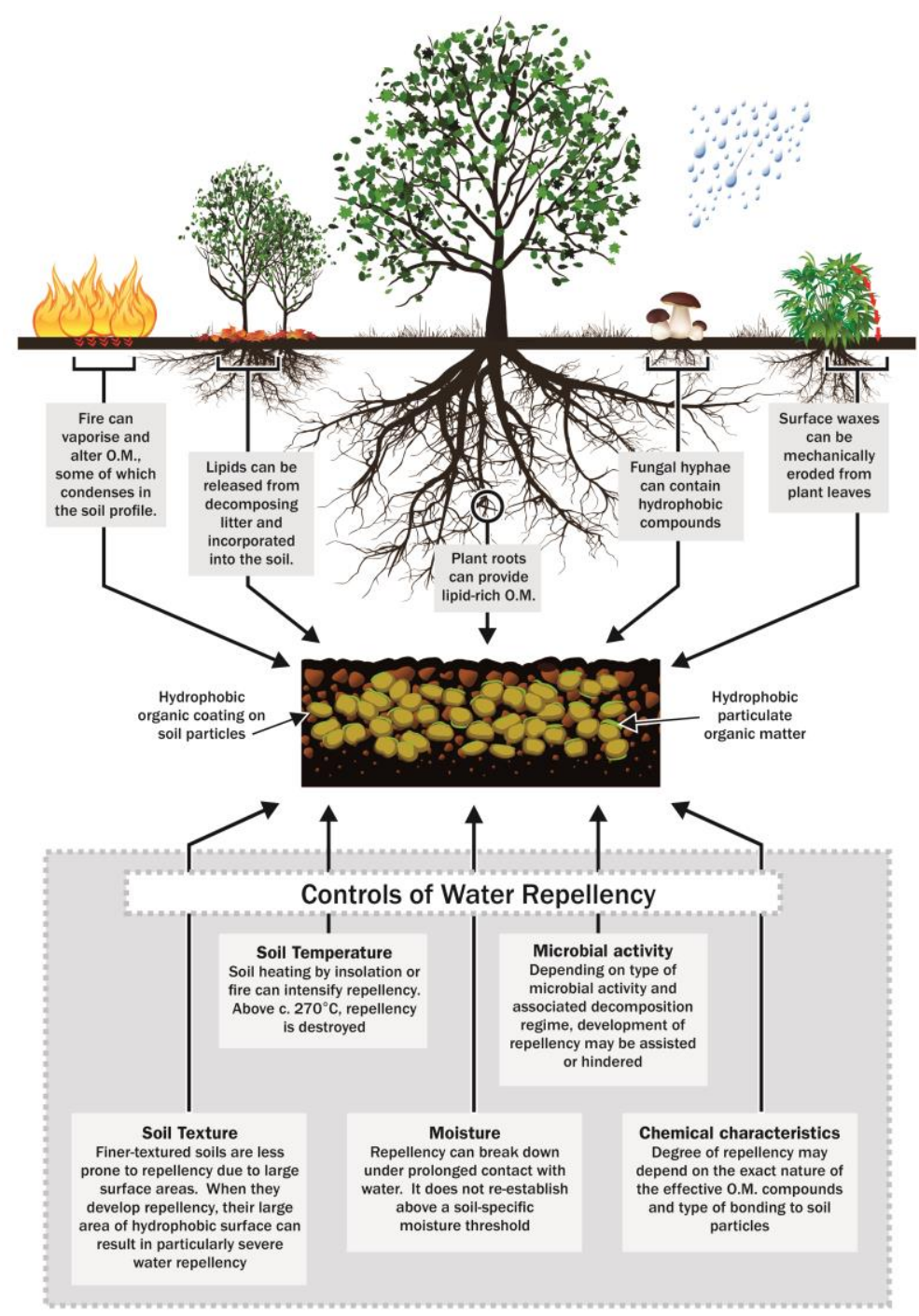

Fig. 1 How water repellency develops, and its controlling factors (adapted from Doerr et al. (2000)).

Emerging tools to overcome soil water repellency in the short-term

Despite considerable research on SWR, it remains a recalcitrant problem for which alleviation technologies or solutions have mixed levels of success in agricultural or restoration activities. Perhaps this failure is due in part to a search for treatments that completely alleviate SWR rather than short-term solutions specifically targeted at seedling establishment. In this research space, recent developments over the past decade include the targeted use of surfactants to overcome SWR such as seed coatings and tree tablets (Madsen et al. 2012; Madsen et al. 2016; Ruthrof et al. 2015; Anderson et al. 2019). These technologies can enhance infiltration and improve water availability in hydrophobic soils (Fig. 2). The combination of water harvesting and treatment of water repellency around the seed resulted in uniform seed emergence, increased soil moisture availability below the seed and improved nutrient uptake (Yeap et al. 2018). Other methods of increasing vigour in water repellent soils have been investigated by Ward et al. (2013), including the use of zero tillage seeding with disc openers, which was shown to preserve old root channels, thus increasing water infiltration in water repellent soil (Roper 
et al. 2013). Clay has been applied to large areas of cropping soils to increase soil reactive surface area in sands (Ward and Oades 1993; McKissock et al. 2000). The use of soil microbes, particularly fungi, to alleviate SWR has potential (Fig. 1), through breaking down SWR, or creating SWR, but is underexplored, though see Roper $(2004,2006)$ (see section: Directions for future research).

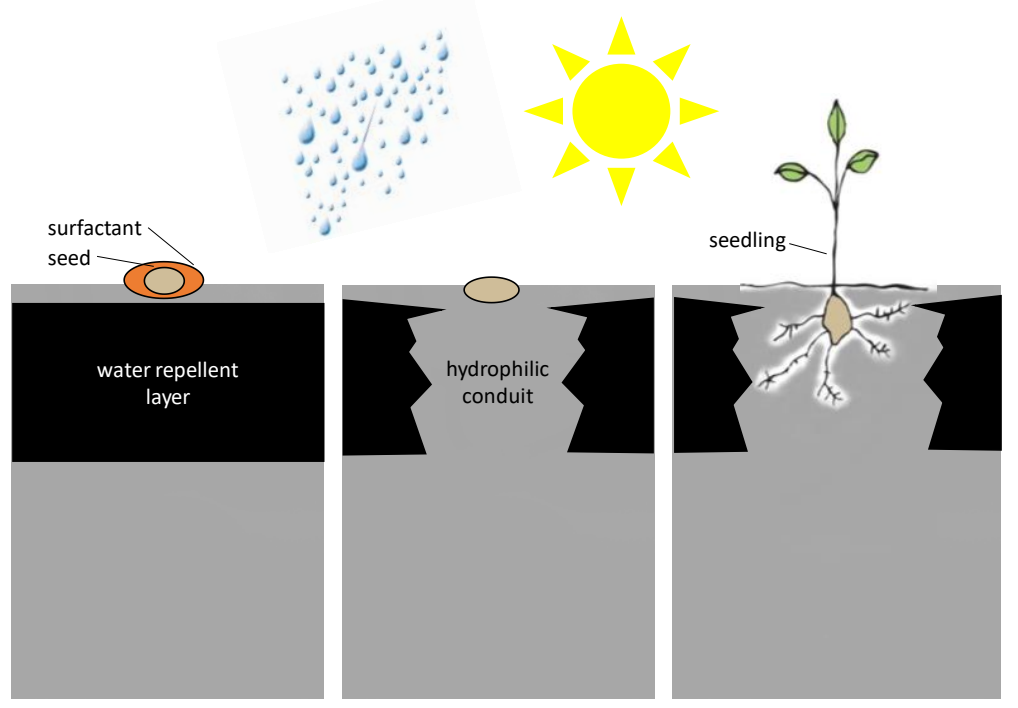

Fig. 2 Illustration of a seed coated with a surfactant (left). Precipitation releases the surfactant into the soil, overcoming soil water repellency and creating a hydrophilic conduit within the microsite of the seed (middle). Enhanced access to soil moisture facilitates seedling survival (right) (reproduced from Madsen et al. (2016), and using Vecteesy.com).

\section{Long-term management}

Soil water repellency may be more severe in native soil than in agricultural soils (Harper et al. 2000). Indeed, inputs of organic matter from native vegetation induced SWR to a greater extent than equivalent amounts of organic matter from agricultural species (Harper et al. 2000; Walden et al. 2015). The contribution of specific residual organic compounds from former native vegetation to SWR in farmland soils is not known but may be significant and help to explain the spatially variable distribution of SWR in these soils (Harper et al. 2000). Indeed, most likely the legacy of former native vegetation contributes to SWR rather than agricultural land use per se (Harper et al. 2000). That said, SWR has been induced under plantation eucalypts established in lands previously used to grow annual pastures, which suggests its expression is sensitive to land-use and specifically to established vegetation (Walden et al. 2015). This last observation is particularly significant, because it suggests SWR can be managed through selection of appropriate land uses and vegetation types. Based on these findings, we have further explored the potential beneficial roles of, and the concept that SWR is an inherent feature of many soils that does not need to be alleviated permanently, but rather, managed. 
129 Perceptions about SWR need to change towards understanding its potential long-term benefits rather 130 than on developing blanket treatments to overcome SWR (Fig. 3). A focus on the beneficial ecological 131 roles of SWR could lead to effective on-ground solutions with significant benefits for conservation, 132 restoration and agricultural activities. The beneficial roles of SWR are evident in the preservation of 133 moisture in soils under native vegetation (e.g. beneath Pinus and Quercus spp. Lozano et al. 2013; see Fig. 3 for further explanation).

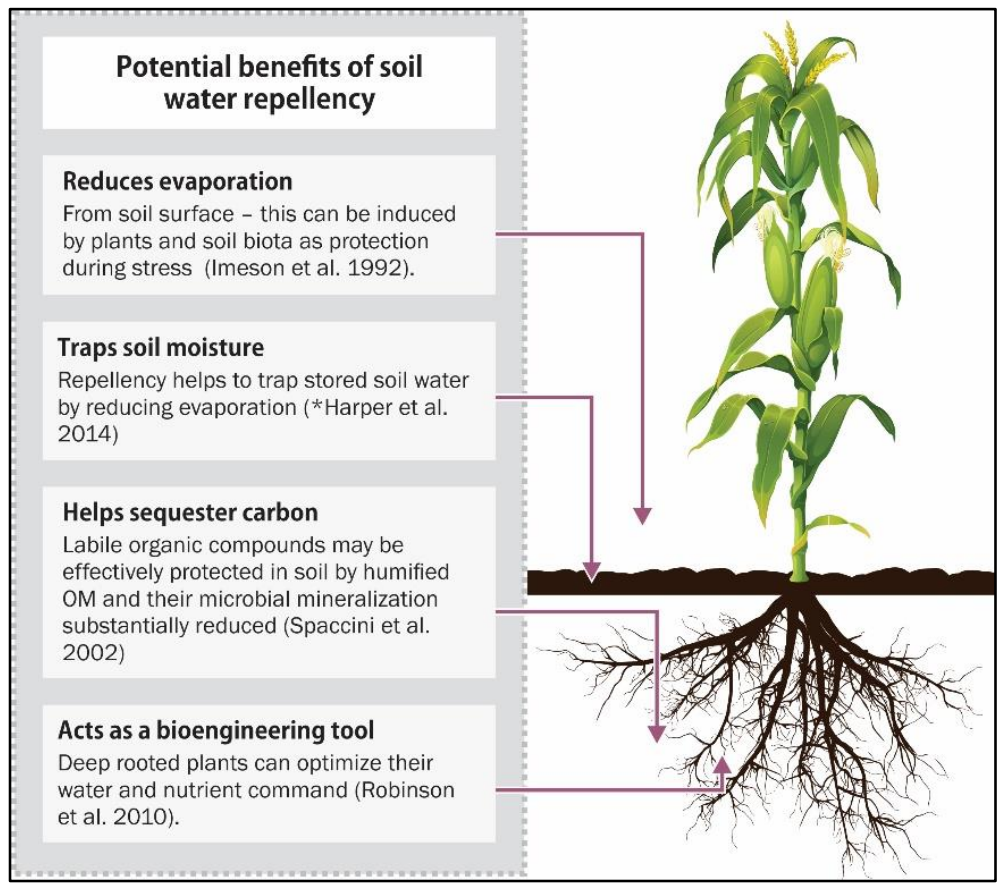

Fig. 3 Potential benefits of soil water repellency.

The ecological implications of SWR in native ecosystems are not fully explained, however, SWR may: a) reduce the loss of soil water by evaporation directly from the soil surface (Imeson et al. 1992; Rye and Smettem 2017), or under water repellent mulches (Hiller and Berliner 1974); b) help sequester carbon (Spaccini et al. 2002; Goebel et al. 2011); and c) act as a bioengineering tool by deep rooted plants to optimize their water and nutrient supply (Müller \& Deurer 2011) (Fig. 3). Furthermore, SWR may inhibit seed germination and water use by potential competing species (Scott 1993).

146 Paradoxically, soil profiles remain moist below water repellent surfaces where there has been little plant 147 growth (Harper et al 2014). The structured patterning of preferential flow pathways created by SWR substances, provide a system for trapping water runoff and for conserving it against evaporation (Imerson et al., 1992; Rye and Smettem). By contrast, there are also plant-soil feedbacks that remain to be explored in this context, in that plants growing in SWR soils may transpire less water. Research to develop deep-rooted perennial farming systems able to cope with uncertain seasonal rainfall, and 
prevent recharge to groundwaters, has suggested the conservation of this stored water may enable plants with deeper roots to access it during drought conditions (Howieson et al. 2008; Harper et al. 2014).

154 Success in this approach has recently been reported by Edwards et al. (2019). Thus, SWR could have marked potential benefit in water-limited ecosystems. The spatio-temporal heterogeneity of SWR and other characteristics could be harnessed to improve plant survival, notwithstanding the need to locally ameliorate SWR around seeds to ensure successful plant establishment. We propose that the key research challenge is to understand SWR with the aim of temporarily overcoming it to successfully and uniformly establish plants, and then preserve it to act as a "drought- proofing" tool.

In a warming climate with predicted increases in extreme events, the stability of soil organic matter is enhanced in water repellent soils as microbes under water stress transfer less carbon to the atmosphere and thus, SWR could be an important soil organic matter stabilisation mechanism in the future (Goebel et al. 2011; Mao et al. 2019). Indeed, Spaccini et al. (2002) found the higher the hydrophobicity of humic material, the larger the soil organic carbon sequestration. However, it is not straightforward to determine the role of SWR in carbon sequestration without more quantitative analyses (Mao et al. 2019).

Soil water repellency could also prevent soil aggregates from breaking down rapidly due to slowing down water infiltration; that is, delayed wetting could protect fragile aggregates from disruptive forces associated with sudden wetting (Bisdom et al. 1993; Zheng et al. 2016). Additionally, as wetting/drying cycles and patchiness alter microbial communities, this could explain why fungi contribute to SWR, as fungi can function at low water potentials (Zheng et al. 2016).

\section{Directions for future research}

175 Microbial activity has been established as one of the most important factors influencing the severity and persistence of SWR (Mao et al. 2019). Soil microbes are intrinsically linked to SWR through their transformation of soil organic matter (Fig. 1). Many species of bacteria produce hydrophobic compounds, which influence the distribution and prevalence of SWR (Mao et al. 2019). Hyphae of fungi and some of their metabolites are also significantly hydrophobic (Lin et al. 2006). The mycelium of the arbuscular mycorrhizal fungi, Glomus intraradices, for example, has been reported to increase SWR (Rillig et al. 2010). Fungal biomass is patchy in space within the soil (Ritz 2007; Tibbett 2000) and so it is reasonable to assume that the deposition of hydrophobic compounds will be similarly patchy. Stimulating microbial biomass with nutrient addition has been shown to enhance SWR in agricultural soil (Hallett and Young 1999), and, although a strong relationship has been reported between fungal biomass and SWR (Feeney 2004; Feeney et al. 2006), another study showed no relationship (Feeney et al. 2006). Clearly these types of interactions, and the mechanisms underpinning them require further investigation, and could include: a) further enhancing microbial growth conditions in order to increase the capacity to record the production of hydrophobic compounds, including altering abiotic conditions 
such as $\mathrm{pH}$ and moisture; b) undertaking measurements at a higher frequency, as SWR may be consumed by other soil organisms and only peaking briefly; and c) as microbes are only able to expand into limited amounts of soil, spatially intensive measurements should be undertaken. Clearly, since these factors, and their interactions illustrate the heterogeneity of SWR in time and space, further research is warranted (Zheng et al. 2016). In addition, research into harnessing these SWR-producing microbes, could lead to, for example, broad-scale agricultural products that could be sprayed onto soils to create a layer of water repellent soil, that retains moisture below the soil surface.

Conversely, bacteria and fungi are also involved in the decomposition of hydrophobic compounds (Lowe et al. 2019) (Fig. 1). For example, inoculation with Rhodococcus spp. and Mycobacterium sp. resulted in significantly lower SWR under laboratory conditions (Roper 2004), and under field conditions, two inoculants, Rhodococcus sp. and Roseomonas sp. resulted in improvements in water infiltration, without any additional nutrients or soil conditioners (Roper 2006). The addition of soil treatments in certain soil types, such as lime, have also been shown to promote the activity by bacteria responsible for wax degradation (Roper 2005). Characterising the molecular basis for microbial determination of SWR, perhaps focusing on fungal communities), is a key area for future research. Traditional and state-of-the-art molecular techniques (genomics and metabolomics), could be used to study spatio-temporal changes in soil microbial activity, the expression of SWR and the interactive effects on plant establishment to improve our knowledge of SWR and methods of overcoming it, such as harnessing native microbes capable of decomposing hydrophobic compounds and creating microbial formations for use in newly developed seed coatings or fertilisers. For example, newly developed seed coatings could contain SWR-degrading microbes plus germination enhancement chemicals such as karrikinolide (Flematti et al. 2004), or, new fertilisers could be formulated to deliver site and cropspecific microbes to target SWR and nutrient limitations simultaneously.

Priorities for future research should include studies to develop an understanding of the dynamics of SWR in soils and to create methods of improving the success of plant establishment. These include developing an understanding of the cause and effect relationship between physico-chemical, microbial dynamics and properties of SWR in native systems at the micro (i.e. plant) to macro scale. For example, which fungal and bacterial communities are associated with soils with SWR, and those without? Furthermore, investigation could be undertaken to develop a range of plant-scale and broadacre, farmscale products and/or management activities that ameliorate SWR at the micro-scale, and yet facilitate SWR at the macro scale to reduce evaporation, to enhance plant survival and community resilience to hotter droughts. For example, can native fungal and bacterial communities capable of breaking down SWR be kept active while encased in seed coating in agricultural systems?

\section{Conclusions}


Soil water repellency is a major challenge to plant establishment and growth. Despite considerable research, it remains a recalcitrant problem for which alleviation solutions have mixed success. We propose a shift from focussing on SWR as a problem, to a focus on its potential long-term benefits. Soil water repellency need only be temporarily alleviated to ensure successful establishment of plants, and then it can be utilised to improve soil water conservation, which in turn will improve the success of conservation, restoration, and agricultural activities. Understanding the role of microbial community dynamics is critical, given the fundamental role microbes play in SWR. Productive lines of enquiry include whether native microbes can be harnessed to manage SWR and whether microbial formulations in seed coatings or plant tablets can reduce SWR at the microscale to increase plant establishment success in conservation, restoration and production landscapes.

Acknowledgements Financial support was provided by ECU Centre for Ecosystem Management, Edith Cowan University (ECU Industry Award and Athena Swan Kick-Start Science Prize) and Murdoch University. The work was partly undertaken under the Centre of Climate Change, Woodland and Forest Health, which is a partnership between private industry, community groups, Universities, and the Government of Western Australia. The authors would also like to thank Jodi Burgess for graphic design (jajographics.com.au).

\section{References}

Bisdom EBA, Dekker LW, Schoute JFT (1993) Water repellency of sieve fractions from sandy soils and relationships with organic material and soil structure. Geoderma 56:105-118.

Blackwell PS (1993) Improving sustainable production from water repellent sands. Western Australian J Agric 34:160-167.

Blackwell PS (2000) Management of water repellency in Australia, and risks associated with preferential flow, pesticide concentration and leaching. J Hydrol 231:384-395.

Bond RD (1964) The influence of the microflora on the physical properties of soils II. Aust. J. Soil Res. 2:123-131.

Daniel NRR, Uddin SMM, Harper RJ, Henry DJ (2019) Soil water repellency: A molecular-level perspective of a global environmental phenomenon. Geoderma 338: 56-66.

DeBano L (1981) Water repellent soils: a state-of-the-art. United States Department of Agriculture. Forest Service. General Technical Report PSW-46.

DeBano LF (2000) The role of fire and soil heating on water repellency in wildland environments: a review. J Hydrol 231:195-206.

Dekker LW, Ritsema CJ, Oostindie K, Boersma OH (1998) Effect of drying temperature on the severity of soil water repellency. Soil Sci 163:780-796.

Dekker LW, Ritsema CJ (1994) How water moves in a water repellent sandy soil: 1. Potential and actual water repellency. Water Resour Res 30:2507-2517. 
263 Diehl D (2013) Soil water repellency: Dynamics of heterogeneous surfaces. Colloids and Surfaces A:

264 Physicochem. Eng. Aspects, 432:8-18.

265 Doerr SH, Shakesby RA, Walsh RPD (2000) Soil water repellency: its causes, characteristics and 266 hydrogeomorphological significance. Earth-Sci. Rev. 51:33-65.

267 Doerr SH, Llewellyn CT, Douglas P, Morley CP, Mainwaring KA, Haskins C, Johnsey L, Ritsema CJ, 268 Stagnitti F, Allinson G, Ferreira AJD, Keizer JJ, Ziogas AK, Diamantis J (2005) Extraction of 269 compounds associated with water repellency in sandy soils of different origin. Aust. J. Soil Res 43:225270237.

271 Edwards TJ, Nutt BJ, Yates RJ, O'Hara GW, Van-Wyk BE, Howieson JG (2019) A ley-farming system 272 for marginal lands based upon self-regenerating perennial pasture legume. Agron Sustainable Dev 273 39:13. doi.org/10.1007/s13593-019-0558-2

274 Feeney DS (2004) Impact of fungi upon soil water relations PhD Thesis. University of Abertay Dundee, 275 United Kingdom.

276 Feeney DS, Hallett PD, Rodger S, Bengough AG, White NA, Young IM (2006) Impact of fungal and 277 bacterial biocides on microbial induced water repellency in arable soil. Geoderma 135:72-80.

278 Flematti G, Ghisalberti EL, Dixon KW, Trengove RD (2004) A compound from smoke that promotes 279 seed germination. Science 304:977.

280 Goebel MO, Bachmann J, Reichstein M, Janssens IA, Guggenberger G (2011) Soil water repellency 281 and its implications for organic matter decomposition - is there a link to extreme climatic events? 282 Global Change Biol 17:2640-2656.

283 Hallett PD, Young IM (1999) Changes to water repellence of soil aggregates caused by substrate284 induced microbial activity. Eur J. Soil Sci. 50:35-40.

285 Harper RJ, McKissock I, Gilkes RJ, Carter DJ, Blackwell PS (2000) A multivariate framework for 286 interpreting the effects of soil properties, soil management and landuse on water repellency. J. Hydrol $287 \quad 231: 371-383$.

288 Harper RJ, Sochacki SJ, Smettem KRJ, Robinson N (2014) Managing water in agricultural landscapes 289 with short-rotation biomass plantations. GCB Bioenergy 6:544-555.

290 Hiller D, Berliner J (1974) Waterproofing surface-zone soil aggregates for water conservation. Soil Sci. 291 118: 131-135.

292 House MG (1991) Select Committee Enquiry into Land Conservation, Legislative Assembly, W.A. 293 Howieson JG, Yates RJ, Foster KJ, Real D, Besier RB (2008) Prospects for the future use of legumes, 294 In: N-fixing Leguminous Symbiosis, vol 7, 363-394.

295 Imeson AC, Verstraten JM, van Mulligan EJ, Sevink J (1992) The effects of fire and water repellency 296 on infiltration and runoff under Mediterranean type forest. Catena 19:345-361.

297 Lin C, Chou W, Tsai J, Lin W (2006) Water repellency of Casuarina windbreaks (Casuarina 298 equisetifolia Forst.) caused by fungi in central Taiwan. Ecol Eng 26:283-292. 
Lowe M, Mathes F, Loke MH, McGrath G, Murphy DV, Leopold M (2019) Bacillus subtilis and surfactant amendments for the breakdown of soil water repellency in a sandy soil. Geoderma 244:108118.

Lozano E, Jimenez-Pinilla P, Mataix-Solera J, Arcenegui V, Barcenas GM, Gonzalez-Perez JA, GarciaOrenes F, Torres MP, Mataix-Beneyto J (2013) Biological and chemical factors controlling the patchy distribution of soil water repellency among plant species in a Mediterranean semiarid forest. Geoderma 207-208:212-220.

Madsen MD, Kostka SJ, Inouye AL, Zvirzdin DL (2012) Postfire restoration of soil hydrology and wildland vegetation using surfactant seed coating technology. Rangeland Ecol \& Manage 65:253-259. Madsen MD, Davies KW, Boyd CS, Kerby JD, Svejcar TJ (2016) Emerging seed enhancement technologies for overcoming barriers to restoration. Restor Ecol 24:S77-S84.

Mao J, Nierop KGJ, Dekker SC, Dekker LW, Chen B (2019) Understanding the mechanisms of soil water repellency from nanoscale to ecosystem scale: a review. JSoils Sediments 19:171-185.

McKissock I, Gilkes RJ, Harper RJ, Carter DJ (1998) Relationships of water repellency to soil properties for different spatial scales of study. Aust. J. Soil Res. 36:495-507.

Múller K, Deurer M (2011) Review of the remediation strategies for soil water repellency. Agr., Eco. \& Env. 144:208-221.

Rillig CM, Mardatin NF, Leifheit EF, Antunes PM (2010) Mycelium of arbuscular mycorrhizal fungi increases soil water repellency and is sufficient to maintain water-stable soil aggregates. Soil Biol. Biochem. 42:1189-1191.

Ritz K (2007) The plate debate: cultivable communities have no utility in contemporary environmental microbial ecology. FEMS Microbiol Ecol 60:358-362.

Roper MM (2004) The isolation and characterisation of bacteria with the potential to degrade waxes that cause water repellency in sandy soils. Aust. J. Soil Res. 42:427-434.

Roper MM (2005) Managing soils to enhance the potential for bioremediation of water repellency. Aust. J. Soil Res. 43:803-810.

Roper MM (2006) Potential for remediation of water repellent soils by inoculation with wax-degrading bacteria in south-western Australia. Biologia Bratislava 61/Suppl. 19:S358-S362.

Roper MM, Ward PR, Keulen AF, Hill JR (2013) Under no-tillage and stubble retention, soil water content and crop growth are poorly related to soil water repellency. Soil \& Tillage Res 126: 143-150. Roper MM, Davies SL, Blackwell PS, Hall DJM, Bakker DM, Jongepier R, Ward PR (2015) Management options for water-repellent soils in Australian dryland agriculture. Soil Res 53:786-806. Ruthrof KX, Bader MKF, Matusick G, Jakob S, Hardy GEJ (2015) Promoting seedling physiological performance and early establishment in degraded Mediterranean-type ecosystems. New For 47:357376.

Rye, K., Smettem, KRJ (2017) The effect of water repellent soil surface layers on preferential flow and bare soil evaporation. Geoderma 207-208: 212-220. 
336 Scott DF (1993) The hydrological effects of fire in South African mountain catchments. J. Hydrol. 337 150:409-432.

338 Spaccini R, Piccolo A, Conte P, Haberbauer G, Gerzabek MH (2002) Increased soil organic carbon 339 sequestration through hydrophobic protection by humic substances. Soil Biol Biochem 34:1839-1851.

340 Tibbett M (2000) Roots, foraging and the exploitation of soil nutrient patches: the role of mycorrhizal 341 symbiosis. Funct Ecol. 14:397-399.

342 Uddin SMM, Daniel NRR, Harper RJ, Henry DJ (2017) Why do biogenic volatile organic compounds

343 (BVOCs) derived from vegetation fire not induce soil water repellency? Biogeochemistry 134:147344161.

345 Walden LL, Harper RJ, Mendham DS, Henry DJ, Fontaine JB (2015). Eucalyptus reforestation induces 346 soil water repellency. Soil Res 53:168-177.

347 Ward PR, Oades JM (1993) Effect of clay mineralogy and exchangeable cations on water repellency in 348 clay-amended sandy soils. Aust J Soil Res 31:351-364.

349 Woche SK, Goebel MO, Kirkham MB, Horton R,Van DerPloeg RR, Bachmann J (2005) Contact angle 350 of soils as affected by depth, texture and land management. Eur J Soil Sci 56:239-251.

351 Yeap SGH, Bell RW, Scanlan C, and Harper RJ (2018) Topsoil water repellence increased early wheat 352 growth and nutrition. Proceedings of the National Soils Conference, Canberra 18-23 November, 2018.

353 Hulugalle N, Biswas T, Greene R, and Bacon P (Eds).

354 Zheng W, Morris EK, Lehmann A, Rillig MC (2016) Interplay of soil water repellency, soil aggregation 355 and organic carbon. A meta-analysis. Geoderma 283:39-47. 